the hospital on the 5th of October in good health. He was seen a few days afterwards in town, and continued well.

REMARKS.

The rapid manner in which the disease yielded in this case is well worthy of notice, especially when we reflect on the danger which usually attends diabetes, and the small number of cases of cure on record. But it may be asked, should the improvement be attributed to the ioduret of iron, to its combination with animal diet and wine, or to the latter alone? These questions are not easily answered; but it must be admitted that the ioduret of iron exercised no small share of influence in the removal of the disease, because the treatment by animal diet, tonics, wine, \&c., had been previously tried for a considerable time without the slightest benefit.-Gazette des Hopitaux, October 20, 1842.

\section{NOTICE OF A MAN WITH THREE} TESTICLES.

The subject of the present notice, William Howard, aged about twenty years, was brought before me at this station on the 28 th ult. (September), as a recruit for the 35th Regiment of Foot.

On looking at him in a state of nudity, as is usual on such occasions, my attention was at once attracted by the appearance of the scrotum, which seemed fuller and larger on the right side than on the left. A minute examination of the part was in consequence made, and the following facts, carefully ascertained, were noted down upon the spot :-

The scrotum was not at all pendulous, but drawn up and corrugated as in a healthy man, so that the difference in size and form between the two sides was very striking.

On applying the hand to the part, one testicle was found in its proper place on the left side of the raphè. In size and form and feeling, also, this testicle was perfectly natural, and may be considered, therefore, as a standard wherewith to compare the others.

On the right side of the raphè, and on the same level as the former, another testicle was found, in all respects perfectly natural, and similar to that on the left side ; and of which, therefore, it may be considered as the proper counterpart.

So far all was perfectly regular; but on this side of the scrotum also (the right), another body was now felt, so similar to the other two just noticed, in size, in form, in feeling, and in consistence, as to leave no doubt of its being a third testicle.

This body was situated within the scrotum, between the groin and the proper testicle of this side, with which, however, it did not seem to be in immediate contact, but to be suspended, as it were, by a shorter cord, or hung up in a separate sac ; in fact, it seemed as if it had dropped from the abdomen after the other, but had not been permitted to fall so low in the scrotum as to touch it. In consequence of this arrangement the lower testicle was not at all pressed upon by the upper.

On the left side the spermatic cord was perfectly natural in all respects, and was easily traced from the groin to the testicle to which it belonged.

On the right side, however, the cord was much thicker than natural at its upper part, where, in fact, it consisted of two cords, one of which was distinctly traced into the upper testicle on this side, and the other, much longer, into the lower testicle. And it is to be particularly noted that in each of those parts, as well as in the cord on the left side, the vas deferens could be distinctly felt, like a piece of whipcord, between the fingers. The three testicles, therefore, were to all appearance perfect, and similar to each other.

The penis was well formed, and all the parts were fully developed, extremely dark, and well furnished with black hair; in fact, there was about the man every indication of vigor and efficiency so far as the parts of generation were concerned, and in all other respects he presented the appearance of a strong, active, well made man; his height was sixty-nine inches, and the circumference of his chest thirty-five. $\mathrm{He}$ was himself perfectly aware of the existence of the third testicle, which had occupied, he said, its present situation as long as he could remember, and had never caused him any inconvenience. I may add, there was no laxity of the inguinal ring on either side, nor any other appearance of local disease.

Anxious to verify the actual state of this man in the most satisfactory manner, I had him brought before me again on the following day, and again examined him minutely in the presence and with the assistance of Dr. Colclough, assistant surgeon 3rd Dragoon Guards, now in garrison here. At this examination every particular of the foregoing detail was investigated anew and fully confirmed, and the conviction was thus, I may say, forced upon our minds, that we had before us the singular spectacle of a man with three testicles. *

Similar cases to the preceding have, I am aware, been seen and recorded by other persons, but having no books here to refer to I cannot venture to make any remark on their peculiarities or on the comparative rarity of such occurrences; with respect to my own experience, however, I may say that I have in the course of my life professionally examined many thousands of men and never met with a similar example.

It only remains for me to add that the man was rejected as a soldier, in consequence of bearing upon his person marks of leeches and cupping; which, together with his general appearance, led to the suspicion that he was a deserter from the service; this, however, he denied, and, in the absence of more direct proof, he could not be detained.

Recruiting Depôt, Coventry, F. MaCann, M.D., Staff Surgeon. October 15, 1842.

$*_{*}^{*}$ If we can believe the older writers, cases of the kind related by Dr. Macann are not very rare, but the only one which possesses any degree of authenticity is that related by Blasius (Obs. Med., p.iv, Obs. 20). Some writers speak of four and even five testicles being found in the same person (Scharff, Eph. Nat. Cur., Dec. iii, An. $v$ and vi, Obs. 89). Buffon admits these facts, but without citing any proof ; and adds that men with three testicles are reputed to be

- Adverting to the symmetrical arrangement of the body I think it very probable that in this and other similar cases a fourth testicle may exist within the abdomen. 
more vigorous than less favored individuals. We must remark, however, that few, if any, of recorded cases of supernumerary testicle have been verified by examination of the body after death, and without such proof some doubt must always remain as to the real nature of the case. If we are allowed to reason from analogy, we should say that the anomaly is much more likely to depend on division of the testicle into two parts than on the existence of a supernumerary organ. There is no example on record of a supernumerary ovary, and the cases of supernumerary kidney observed always depended on division of that organ, by the separation of one or more of its primitive lobules, and not on actual increase in number. Examples of supernumerary mammæ are numerous ; but this is easily explained by the fact of such being the natural disposition of parts in many animals; for it is a well-known law of anomalies, that many deviations observed in the human subject are but repetitions of the normal condition of inferior animals.-EDs.

\section{PROVINCIAI, MEDICAL JOURNAL}

\section{SATURDAY, NOVEMBER 5, 1842.}

A case was tried last week at Barnstaple which requires notice, as it involves a point of law materially affecting the interests of the medical profession. $\mathbf{M r}$. Joce, a respectable general practitioner, residing at Barnstaple, brought an action against a lieutenant in the navy, named Shapland, for medical attendance.

The defendant pleaded the statute of limitations with respect to a large portion of the debt; the remainder, $£ 219$ s. $9 \mathrm{~d}$, he admitted on the record. It is unnecessary for us to notice the opening speech of $\mathrm{Mr}$. Joce's counsel, as it referred to matters unconnected with the point to which we are desirous of directing attention. This point is the alleged necessity of proving the seal of the Apothecaries' Company, in cases where an action for debt is brought by a member of the company.

On the part of the plaintiff, Mr. Joce, an attempt was made to prove the seal by the evidence of several medical men, who had formerly received licenses from Apothecaries' Hall, and who testified to the similarity between the seal attached to Mr. Joce's license and their own.

Mr. Praed, the Recorder of Barnstaple, before whom the case was tried, decided that such evidence was insufficient.

"The court (said Mr. Praed) was quite clear that the seal must be proved; some person should be produced, either an officer of the Apothecaries' Company or some other person capable of speaking to it with certainty, from un actual knowledge of, and comparison with, the original seal itself; the witnesses produced proved nothing, for they never saw it; there should have been an officer of the company in court; he (the recorder) had often seen an officer produced in cases of this sort."
Mr. Joce's counsel was not prepared to bring forward any evidence of the kind required by the court, and Mr. Joce was accordingly non-suited.

The case will, we understand, be submitted to a higher tribunal; but we cannot avoid expressing our opinion that the plaintiff's attorney ought to have been prepared, either to prove the seal of the company, or, at least, the handwriting of one or more of the persons whose names were attached to the license.

The point of law upon which Mr. Joce was defeated is by no means a new one; it has been debated over and over again in courts of justice. It is agreed upon all hands that the certificate must be proved, and the only question which remains is, what is considered sufficient proof in a court of law. The Re. corder of Barnstaple seems to think that it is necessary to prove the seal of the court, but herein we believe him to be in error. Several of the judges have decided that it is merely necessary to produce the original certificate granted to the plaintiff, and to give reasonable evidence of its being a genuine document. This may be done by proving the signature of one or more of the persons whose names are attached to the certificate as examiners, and showing that such persons acted as examiners at the time of signing the document.

The 6th of George IV., by which the common seal of the company was rendered sufficient proof of the authenticity of the certificate, expired in August, 1826; and the mode now to be adopted for proving the certificate must be the one which was in use before the passing of that act in July 1825 .

To illustrate this mode we have merely to cite one of the numerous cases on record. Thus, in Walmsley v. Abbot (1 Carring. and Payn. 309, 5 George IV.), it is reported that, "a witness produced the certificate of the plaintiff's examination at Apothecaries' Hall, and proved that the signature of Mr. Simmons was of his handwriting, and that he acted as an examiner there; and that the certificate produced was the usual certificate given to persons who had passed their examinations."

The defendant's counsel having made some objection to the validity of the proof, Mr. Baron Garrow said, "That if it were proved that this was the usual form of certificate, and there were proof of the handwriting of one of the examiners, and that that person acted as an examiner, he would admit the certificate;" and this having been done, the plaintiff obtained a verdict. From what we have said, it seems clear that $\mathrm{Mr}$. Joce's case broke down from want of sufficient evidence to prove the authenticity of his certificate; but the decision of the recorder on the necessity of proving the company's seal will probably be reversed by the higher tribunal before which $\mathrm{Mr}$. Joce is determined to bring it. Such appeal, however, must be attended with very considerable expense, and unless some 